\title{
THE IMPACT OF DIGITAL AUDIO-TEXT AND AUDIO-VISUAL INSTRUCTIONAL MEDIA ON LEARNING OF CULTURAL AND CREATIVE ARTS (CCA) AMONGST JUNIOR SECONDARY SCHOOLS STUDENTS IN RIVERS STATE, NIGERIA
}

\author{
AWAJIOKINOR EKRIKA MBABA \\ Department of Curriculum \& Instruction
}

ABIODUN JIMOH

Department of Foundation Studies

\author{
GARBA MOHAMMED BAKORI
}

Department of Adult \& Non-Formal Education

Isah Kaita College of Education, Dutsinma, Nigeria.

\begin{abstract}
The study evaluated students' interest on the use of digital text-audio and audio-video in teaching Cultural and Creative Arts. The study was carried out in Andoni Education Zone of Rivers State among Junior Secondary Schools. The research design adopted for the study was quasi experimental. A total of 183 Junior Secondary two (JSS II) CCA students were sampled from the population of 2118 for the study. The sampled size is made up of 99 males and 84 females. Digital text-audio and audio-video instructional packages were used to present lessons to students in six weeks. A 15-item questionnaire was used in collecting data. Data collected for answering research questions and testing hypotheses were analysed using mean, standard deviation and Analysis of Covariance (ANCOVA) respectively. The results showed that both digital text-audio and audio-video instructional packages improved students' interest. The authors recommend that governments should improve infrastructure in schools to enhance effective use of technology in the classroom.
\end{abstract}

Keywords: $\quad$ Digital Text, Audio-Visual, Instructional Media

DOI: $\quad$ https://doi.org/10.35386/ser.v18i1.53

\section{Introduction}

Students' interest does influence learning of subjects including Cultural and Creative Arts. It has been observed that most often performance of students is high when it comes to subject that students are really interested in learning. Research has demonstrated that both situational and individual interest promote attention, recall, task persistence, and effort (Ainley, Hidi, \& Berndorff, 2002; Hidi \& Renninger, 2006). The challenge of the teacher has been how to harness strategies; materials and equipment from the environment to ensure both situational and individual interest are positively employed in learning. This is where the effectiveness of the teacher becomes a factor in students' performance (Saurer, 2012). When a teacher engages and motivates students using better approach students are more likely to participate in class activities and demonstrate their abilities. Therefore, teacher's role and effectiveness are crucial in determining student good performance. Moreover, some studies have shown that the use of technology in teaching improves students' interest in the subject and their performance (Igboanugo, 2013). Thus, the need to evaluate students' interest in the use of digital text-audio and audio-video in teaching Cultural and Creative Arts. 
The Impact of Digital Audio-Text and Audio-Visual Instructional Media on Learning of Cultural and Creative Arts (CCA) Amongst Junior Secondary Schools Students in Rivers State, Nigeria

Interest as defined by Philip (2011) is a feeling or emotion that causes attention to focus on an object or a process. It is a mental state evoked by something like quality, subject or activity. It means to cause someone to become involved in something. Peet (2010), sees interest as learning to do something because you need it in order to do what you want to do. It means learning to read because one wants to discover new things through the reading, or create mental pictures of a fantasy world, which intrigues one. But, to Harackiewiez \& Hulleman (2010) colloquially, being interested in something can mean that we care about it, that it is important to us and that we have (mostly) positive feelings towards it. We often say things like, "I'm interested in the well-being of my child," "I'm interested in playing football this fall," and "I have a research interest in social psychology." etc. However, interest can also be more fleeting, such as when we see an interesting TV program, or an unexpected noise arouses our curiosity. Dewey cited in Harackiewicz \& Hulleman (2010) stated that interest is described as engaged, engrossed, or entirely taken up with, an activity, object, or topic. More contemporary interest theorists have also divided interest into two components: individual interest and situational interest. Individual interest is more enduring, and trait-like, and endures over time. It can be considered a disposition that individuals take with them from one context to the next (Renninger, 2000; Harackiewicz \& Hulleman 2010).

Interest can be brought about through reinforcement. Peet (2010) stated that reinforcement and reward - driven interest in learning can alter the probability of behaviors that precede them, as Thorndike captured in his law of effect. Sutton, Richard and Andrew (1998) also stressed that this type of interest in learning is shown so as to maximize notion of cumulative reward. Such interest in learning can be seen in stimulus - based optimization. The power of imagination plays a crucial role in creating interest in learners. This is called the "interest approach", and it is very effective and widely applicable (Benge \& Harder, 2011).

Interest is important in learning as it plays a critical role in the development of a person's thinking ability (Benge \& Harder, 2011). According to the authors, learners' interest existing in any given topic flows into any other, as soon as a connection between the two is seen. This brings about a permanent learning. Interest has a cognitive as well as an affective component as a motivational construct (Hidi \& Harackiewicz, 2000). Xiang, Chen and Bruene (2005) reported that interest emerged as the most important intrinsic motivation construct for predicting future intention. In addition, they also found out that interest seemed to override the effects of both extrinsic rewards and other intrinsic motivation sources. Taken collectively, the literature on interest-based motivation indicates that interest might have a strong and prolonged effect on learner motivation and in predicting future intention (Hidi, 2000).

Interest in learning can be explained in three areas: individual interest, which is a personal quality that is quite stable and fluctuate little; situational interest, which is an emotional state elicited by amusing mathematics-related activities or the content of teaching materials; and interest-induced psychological state that occurs when an individual is showing intense interest in something, focuses all attention on what sparks that interest, while ignoring anything else in the surroundings. Interest could be generated in a classroom setting to offer meaningful options to students by: selecting well-compiled teaching materials; selecting teaching materials that are full of variation and also liveliness; selecting teaching materials that students have 
prerequisite knowledge of; encouraging students to be active participating learners; giving hints/reminders immediately relevant to students; putting to use ideas of novelty and variation; and helping the teacher set an example by showing passion and interest about what is being taught (Schraw \& Lehman, 2010; Yu-Je, Chia-Hus Ching-yaw., 2011).

Interest of learners could be improved through appropriate teaching approaches or strategies, interest in a subject is also seen as a reflection of what the students like doing with profound pleasure and enthusiasm. Students' interest in CCA/ vocation subjects can help teachers prepare students towards that vocation instead of allowing them to be influenced by factors that could overrun their interest and push them into careers they have no flair for. Interest does determine students' level of achievement, for instance a number of researches on students' interest in CCA have shown that when students' interest is low, achievement are usually low as well (Toyobo \& Oyegoke, 2011). Chukwu (2012) studied the effect of picture and visualization on students' achievement and interest in essay writing in English language. The use of picture technique in teaching essay writing appeared to be outstandingly more efficacious, in drawing the interest of the students and slightly more effective in the actual creative imagination required by learners. The study supports the fact that teaching approach is also capable of influencing students' interest positively or negatively.

Moreover, Ogboji (2013) investigated the effect of local resources on students' achievement and interest in Cultural and Creative Arts in Nsukka, The findings also indicated that effective use of resources, be it local or commercial are capable of arousing students' interest in CCA. In addition, Igboanugo (2013) investigated the effect of peer teaching on students' achievement and interest in senior secondary schools difficult chemistry concepts in Onisha Education Zone. The result of the study shows that peer-teaching arouses and sustains students' interest more than lecture method.

\section{Rationales for Evaluating Learner Interest on Subjects}

It is interest that drives an individual's curiosity and it's a key force in driving learning and discovery of new knowledge and better understanding. Based on this, the relationship between interest and learning has been investigated since the start of the 19th century (Krapp, Hidi \& Renninger, 2015).

The reason for the study of interest is growing based on body of evidence which indicates that increased interest in a subject can increase student attainment (Hulleman \& Harackiewicz, 2009). More so, interest has a profound positive impact on an individual's attention levels, recall of information, persistence and effort in the pursuit of knowledge (Hidi \& Renninger, 2006; Krapp \& Prenzel, 2011; Mitchell, 1993), all of which are important for the individual and for classroom practice. Moreover, the need for students to see activities as meaningful is a supportive factor of interest development which appears in most interest research (for example, Krapp \& Prenzel, 2011). 


\section{Statement of the Problem}

Cultural and Creative Arts was developed and introduced as core subjects in the UBE curriculum. CCA is an amalgamation of contents of Creative Arts (Fine and Applied Art, Music and Dama). It is rooted in drawing and design-based works such as painting, print making, sculpture, ceramic, textile design, music and drama. The teaching of CCA is done using traditional method. As a result, it was observed that students' interest in the subject has declined and this could be attributed to poor method used in teaching the subject. Moreover, lack of innovations also remains a factor as far as low students' interest is concerned. It is observed that some students' interest might have been demoralized as a result of the absence of alternative teaching approaches. Because, interest can be developed or improved with good strategies especially when learning is student-centred. Thus, the need to evaluate the effect of digital text-audio and digital audio - video instruction on students' interest in CCA.

\section{Objectives of the Study}

The objectives of this study are to:

1. determine the effect of digital text -audio and audio - video on students' interest in Cultural and Creative Arts;

2. determine the effect of digital text -audio and audio -video on male and female students' interest in CCA.

\section{Research Questions}

The following questions were raised to guide the study;

1. What is the effect of digital text-audio and audio-video on students' interest in Cultural and Creative Arts?

2. What is the effect of digital text -audio and audio -video on male and female students' interest in CCA?

\section{Hypotheses}

The following hypotheses were formulated and tested at 0.05 level of significance:

$\mathrm{HO}_{1}$ There is no significant difference between the interest of students, taught CCA using digital video-audio and those taught using digital text-audio.

$\mathrm{HO}_{2}$ There is no significant difference between the interest of male and female students taught CCA using digital text-audio and those taught using digital audio-video.

\section{Research Design}

The research design adopted for this study was quasi-experimental with pre-test and post-test. It is a type of enquiry where one ought to include manipulation of an independent variable that serves as the treatment or intervention; and randomization of the subject with respect to treatment conditions (Kothari, 2011). 


\section{Population of the Study}

The population of this study consisted 2,118) Junior Secondary School Two (JSSII) students from 13 public Junior Secondary Schools in Andoni education zone. This population comprises 1,107 male and 1,011 female students

\section{Sample and Sampling Technique}

A total of 183 Junior Secondary Two (JSS II) CCA students were sampled for the study using simple random sampling. The sampled size is made up of 99 males and 84 females from two coeducational schools sampled for the study. Purposive sampling technique was used to obtain the public schools with mixed gender composition and have the required facilities needed.

\section{Research Instrument}

The Cultural and Creative Art Interest Inventory (CCAII) is a 15-items interest scale on Cultural and Creative Art developed by the researchers. It has a four point response scale of strongly agreed $=4$, agreed $=3$, disagreed $=2$ and strongly disagreed $=1$. The respondents are expected to indicate their degree of agreement or disagreement on a number of statements, positive and negative alike on Cultural and Creative Art in general and portraying students' level of interest in Cultural and Creative Art

\section{Validation of the Instrument}

CCAII was given face and content validation by two lecturers from the department of Arts Education University of Nigeria Nsukka, and one lecturer from Science Education University of Nigeria Nsukka, this is to ascertain the clarity of the statements, appropriateness of the items to the level of the students and suitability for the study. Based, on the recommendations of these experts the instrument was given some corrections before the final draft for this study was produced.

\section{Reliability of the Instrument}

The validated instrument (CCAII) was trial tested on 20 JSSII students in two Junior Secondary Schools in Andoni (Community Secondary School Ebukuma and Government Junior Secondary School Ngo). These students were not part of the real study. Cultural and Creative Arts Interest Inventory (CCAII) internal consistency was ascertained using the Cronbach Alpha Statistic which yielded a reliability index of 0.81. The Cronbach Alpha Statistic was used because the items were scored polychotomously. This means the instrument has no yes or no answers.

\section{Procedure for Data Collection and Analysis}

The validated CCAII was administered to all the sampled students as pre-test after which text-audio and audio-video instructional packages were given as treatment for six weeks. The CCAII was reshuffled and re-administered as post-test. The data collected was analysed using mean and standard deviation to answer research 
The Impact of Digital Audio-Text and Audio-Visual Instructional Media on Learning of Cultural and Creative Arts (CCA) Amongst Junior Secondary Schools Students in Rivers State, Nigeria

question. While Analysis of Covariance (ANCOVA) with pre-test as a covariate was used to test the hypotheses formulated for the study at 0.05 level of significance.

\section{Results}

Research Question: 1 What is the effect of multimedia digital text -audio and audio video on students' interest in Cultural and Creative Arts?

Table 1: $\quad$ Mean Interest Scores ofStudents taught Cultural and Creative Art in Junior Secondary Schools with digital text-audio and audiovideo.

\begin{tabular}{lllllll}
\hline Method & $\mathrm{N}$ & $\begin{array}{l}\text { Pretest } \\
\text { Mean }\end{array}$ & SD & $\begin{array}{l}\text { Posttest } \\
\text { Mean }\end{array}$ & SD & Mean Gain \\
\hline Text Audio & 97 & 1.81 & 0.44 & 2.75 & 0.34 & 0.94 \\
Audio Video & 86 & 1.71 & 0.49 & 3.18 & 0.40 & 1.47 \\
\hline
\end{tabular}

Table 1 shows the pretest mean interest score of text-audio group to be 1.81 with SD of 0.44 while audio-video group had a mean of 1.71 with SD of 0.49 . This result shows that both groups' mean interest levels were close as indicated by the means and standard deviations. The posttest mean interest scores of the text-audio and audiovideo groups are 2.75 with SD of 0.34 and 3.18 with SD of 0.40 respectively. The result indicates that after treatment students' interest was improved. The text-audio group had a mean gain of 0.94 while audio-video group had a mean gain of 1.47 . The result shows that the interest of theaudio-video group improved higher than that of the text-audio group.

Research Question 2: What are the mean interest scores of male and female students in CCA?

Table 2: Interest Mean and Standard Deviation of Male and Female Students taught Cultural and Creative Arts using text-audio and audio-video

\begin{tabular}{lllllll}
\hline Gender & $\mathrm{N}$ & $\begin{array}{l}\text { Pretest } \\
\text { Mean }\end{array}$ & SD & $\begin{array}{l}\text { Posttest } \\
\text { Mean }\end{array}$ & SD & Mean Gain \\
\hline Male & 99 & 1.77 & 0.47 & 2.93 & 0.45 & 1.16 \\
Female & 84 & 1.75 & 0.46 & 2.99 & 0.41 & 1.24 \\
\hline
\end{tabular}

Table 2 presents pretest and posttest mean interest scores and standard deviations of male and female students taught CCA. The pretest mean interest score of male students is 1.77 with SD of 0.47 while that of their female counterparts is 1.75 with SD of 0.46 . The posttest mean interest scores of male and female students are 2.93 with SD of 0.45 and 2.99 with SD of 0.41 respectively. The males had a mean gain of 1.16 while their female counterparts had a mean gain of 1.24 . The result shows that the interest of female students improved slightly higher than that of their male counterparts.

$\mathrm{HO}_{1}$ : There is no significant difference between the interest scores of students taught CCA using digital video-audio and those taught using digital textaudio. 


\begin{tabular}{|c|c|c|c|c|c|c|}
\hline Source & $\begin{array}{l}\text { Type III Sum } \\
\text { of Squares }\end{array}$ & Df & Mean Square & $\mathrm{F}$ & Sig. & Decision \\
\hline Corrected Model & $8.660^{\mathrm{a}}$ & 2 & 4.330 & 30.944 & .000 & \\
\hline Intercept & 108.280 & 1 & 108.280 & 773.814 & .000 & \\
\hline Pretest & .051 & 1 & .051 & .364 & .547 & \\
\hline Method & 8.397 & 1 & 8.397 & 60.010 & .000 & $\mathrm{~S}$ \\
\hline Error & 25.187 & 180 & .140 & & & \\
\hline Total & 1630.825 & 183 & & & & \\
\hline Corrected Total & 33.847 & 182 & & & & \\
\hline
\end{tabular}

a. R Squared $=.256$ (Adjusted R Squared $=.248)$

$\mathrm{S}-$ Significant $(\mathrm{p}<0.05)$

Table 3 presents F- value as 60.010. This value is significant at .000 . Since this value is less than 0.05 level of significance, the hypothesis is rejected. Therefore, there is a significant difference between mean interest scores of students taught Cultural and Creative Art in Junior Secondary Schools with digital text-audio and those taught with multimedia digital audio- video in favour of audio- video group.

$\mathrm{HO}_{2}$ : There is no significant difference between the mean interest scores of male and female students taught CCA.

Table 4: $\quad$ Summary of ANCOVA for Mean Interest Scores of male and female Students taught Cultural and Creative Art in Junior Secondary Schools

\begin{tabular}{lllllll}
\hline Source & $\begin{array}{l}\text { Type III Sum } \\
\text { of Squares }\end{array}$ & Df & \multicolumn{2}{l}{ Mean Square F } & Sig. & Decision \\
\hline Corrected Model & $.431^{\mathrm{a}}$ & 2 & .215 & 1.160 & .316 & \\
Intercept & 113.897 & 1 & 113.897 & 613.510 & .000 & \\
Pretest & .255 & 1 & .255 & 1.375 & .243 & \\
Gender & .168 & 1 & .168 & .904 & .343 & NS \\
Error & 33.417 & 180 & .186 & & & \\
Total & 1630.825 & 183 & & & & \\
Corrected Total & 33.847 & 182 & & & & \\
\hline
\end{tabular}

a. R Squared $=.013$ (Adjusted R Squared $=.002$ )

NS - Not Significant $(p>0.05)$

Table 4 shows that F-value of .904 has a probability value .343 . This probability value is greater than 0.05 level of significance; as a result, the null hypothesis is not rejected. Therefore, there is no significant difference between the mean interest scores of male and female students taught Cultural and Creative Art in Junior Secondary Schools.

\section{Discussion}

The result shows that the post interest mean scores were efficacious in favour of audio - video group. This result also supports the earlier work of Chukwu (2012) which investigated the effect of imagery techniques (pictures and visualization) on students 
The Impact of Digital Audio-Text and Audio-Visual Instructional Media on Learning of Cultural and Creative Arts (CCA) Amongst Junior Secondary Schools Students in Rivers State, Nigeria

achievement and interest and revealed that the interest mean scores of students in the experimental group was high hence techniques or approach influences students interest. The result of this present study also supported Igboanugo (2013) who investigated the effect of peer-teaching on students achievement and interest, the findings shows that peer-teaching arouse students' interest more than lecture method. This means a well taught out approach or strategy to teaching posses the chances of enhancing students' interest as found in this present study. However, the present study disagree with Ogboji (2013) whose study states that approach does not influence students interest as students taught with local resources and commercial resources does not have any difference in their interest mean scores.

Data presented from the study reveals that students' interest is not influenced by gender. Based on the data, the slight difference observed is in favour of female. But, the difference is not significant. Thus, gender has no influence when digital text audio and audio - video is used in teaching CCA. The present study is in agreement with Chukwu (2012) who investigated effect of imagery techniques (pictures and visualization) on students' achievement and interest in essay writing in English language. The study also examines the influence of gender on students' interest and found out that influence of gender on interest was not significant, hence the observed slight high interest mean scores was not significant.

\section{Conclusion}

The study of Students' interest in learning different subjects has been investigated overtime. Interest can be developed since it is influenced by situation and individual, hence the use of approach or strategy that makes teaching easy and learner centred such as the one found in digital text-audio and audio-video will enhance the teachers' effort by keeping the classroom lively with high interaction, this interaction improves students' interest. Thus, this study has shown that teachers of Cultural and Creative Arts can improve their students' interest in the subject with the use of digital textaudio and audio-video instructional packages.

\section{Recommendations}

1. Teachers should ensure they consider students interest in the subject they teach as this is key to getting them perform better.

2. Teachers should always ensure a change of teaching methods or approaches to get rid of boredom classroom.

3. The use of multimedia approach should be encouraged among teachers

4. Government should improve infrastructures in schools to enhance effective use of technology in the classroom. 


\section{References}

Ainley, M., Hidi, S., and Berndorf, D. (2002). Interest, learning and the Psychological process that mediate their relationship. Journal of Educational Psychology, 94, 545-561.

Benge and Harder (2011). Agricultural Education and Communication. Florida: Florida State University.

Chukwu, C. R. (2012). Effect of imagery and gender on secondary school students' achievement and interest in essay writing in Anambra State. Unpublished M.Ed thesis presented to the department of Arts Education University of Nigeria, Nsukka.

Harackiewiez, J. M. \& Hulleman, C. S., (2010). Importance of interest: The role of achievement goals and task values in promoting the development of interest, Social Personality Psychology Compass, 4 (1): 42-52.

Hidi, S. (2000). An interest researcher's perspective: The effect of intrinsic and extrinsic factors on motivation. In C. Sansone \& J. M. Harackiewicz (Eds.), Intrinsic and extrinsic motivation: The search for optimal motivation and performance (309-339). San Diego, CA: Academic Press

Hidi, S. \& Harackiewicz, J. M. (2000). Motivating the academically unmotivated: A critical issue for the 21st century. Review of Educational Research, 70, 151179.

Hidi, S. and Renninger, K. A. (2006). 'The Four-Phase model of interest development'. Educational Psychologist, 41 (2), 111-127.

Hulleman, C. and Harackiewicz, J. M. (2009). 'Promoting interest and performance in High School Science Classes'. Science, 326, 1410-1412

Igboanugo, B. I. (2013). Effects of peer-teaching on students' achievement and interest in senior secondary school difficult chemistry concepts. International Journal of Educational Research, 12 (2), 61-71.

Kothari, C. R. (2011). Research methodology. Second revised edition, New Age International Publishers. Delhi.

Krapp, A., Hidi, S. and Renninger, K. A. (2015). 'Interest, learning and development'. In K. A. Renninger, S. Hidi and A. Krapp (Eds.), The Role of Interest in Learning and Development (pp. 3-26). New York: Psychology Press.

Krapp, A. and Prenzel, M. (2011). 'Research on Interest in Science: Theories, methods, and findings'. International Journal of Science Education, 33 (1), 27-50. 
The Impact of Digital Audio-Text and Audio-Visual Instructional Media on Learning of Cultural and Creative Arts (CCA) Amongst Junior Secondary Schools Students in Rivers State, Nigeria

Lehman P. (2001). What students should learn in Arts Content of the Curriculum. Alexanderia, VA, Association for Supervision and Curriculum Development.

Mitchell, M. (1993). 'Situational Interest: Its Multifaceted Structure in the Secondary School Mathematics Classroom'. Journal of Educational Psychology, 85 (3), 13.

Peet, W. (2010). Interest driven learning: Dr Peet"s personal talking writing laboratory for beginning readers: Dr Peet's Software, LLC. Retrieved from http://www.drpeet.com.

Ogboji, B. A. (2013). Effect of local resources on students' achievement and interest in Cultural and Creative Arts in Nskka, Enugu State. Unpublished thesis presented to the Department of Arts Education, University of Nigeria Nsukka.

Philip, L. (2011). Interest. Roget's 21st Century Thesaurus (3rd ed). Retrieved May 7, 2012, from http://www.thesaurus.com/browse/interest.

Saurer, K. (2012). The impact of students' interest and instructor effectiveness of student performance. A thesis presented to St. John Fisher College. Available at http://fiserpub.sjfc.edu/edcation

Schraw, G. and Lehman, S., (2010). Situational interest: a review of literature and directions for future research. Educational Psychology review, 13 (1), 23-52.

Sutton, A., Richard, S. \& Andrew, G. (1998). Reinforcement learning: An Introduction. MIT Press.

Renninger, K. A. (2000). Individual interest and its implications for understanding intrinsic motivation. In C. Sansone \& J. M. Harackiewicz (Eds.), Intrinsic and Extrinsic Motivation: The Search for Optimal Motivation and Performance (pp. 373-404). San Diego, CA: Academic Press, Inc.

Xiang, P., Chen, A. \& Bruene, A. (2005). Interactive impact of intrinsic motivators and extrinsic rewards on behavior and motivation outcomes. Journal of teaching in Physical education (24): 179-197. Retrieved from psycned.apa.org/reward/2005-04870004.

Yu-je L., Chia-Hus, C. \& Ching-yaw, C. (2011). The influence of interest in learning and learning hours on learning outcomes of vocational college students in Taiwan: using a teachers' instructional attitude as the moderator. Global Journal of Engineering Education, 13 (3), 140-153. 